
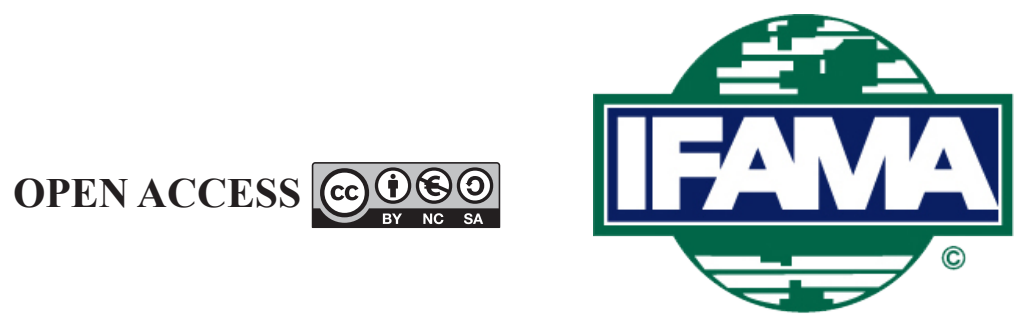

International Food and Agribusiness Management Review

Volume 23, Issue 2, 2020; DOI: 10.22434/IFAMR2019.0166

Received: 10 June 2019 / Accepted: 20 January 2020

\title{
Farmer satisfaction and cocoa cooperative performance: evidence from Tocache, Peru
}

\section{RESEARCH ARTICLE}

\author{
Angie Higuchi $^{\circledR a}$, Daniel Coq-Huelva ${ }^{\text {b,c }}$, Ruth Arias-Gutierrez ${ }^{\mathrm{d}}$ and Rafaela Alfalla-Luque \\ aProfessor, Department of Business administration, Universidad del \\ Pacifico, Av. Salaverry 2020 Jesus Maria, Lima 11, Peru \\ ${ }^{b}$ Professor, Department of Applied Economics II, Universidad de Sevilla, \\ Avenida Ramón y Cajal 1, 41018 Sevilla, Spain \\ cProfessor, Instituto de Estudios sobre América Latina, Avenida de la Ciudad Jardín 20-22, 41005 Sevilla, Spain \\ ${ }^{d}$ Professor, Universidad Estatal Amazónica, Km 21⁄2, Vía Puyo a Tena (Paso Lateral), Puyo 160101, Ecuador \\ ${ }^{e}$ Professor, Department of Financial Economics and Operations Management, \\ Universidad de Sevilla, Avenida. Ramón y Cajal 1, 41018 Sevilla, Spain
}

\begin{abstract}
Cocoa marketing cooperatives are essential in the current model of governance of cocoa production and distribution in Peru and other developing countries. Because farmer satisfaction is particularly important for the success and development of cooperatives, this article focuses on an analysis of the factors related to farmer satisfaction as well as the identification of demographic and socio-economic elements that can explain the different levels of satisfaction among different cooperative members. Data obtained through a survey of 150 cocoa farmers were analyzed through three main statistical methods: (1) an exploratory factor analysis with a principal component analysis method; (2) cluster analysis; and (3) an independent samples $t$-test. The results confirm that farmer satisfaction is explained by a complex set of cognitive and psycho-social elements and pro-social emotions. Finally, the results indicate that some socio-economic features such as farm size or household size are associated with the varying existing levels of farmer satisfaction.
\end{abstract}

Keywords: cocoa, cooperative, Peru, exploratory factor analysis, cluster analysis JEL code: C13

\footnotetext{
${ }^{(1)}$ Corresponding author: a.higuchi@up.edu.pe
} 


\section{Introduction}

On a global scale, the relevance of cooperatives has also been stimulated by a series of transformations in agri-food value chains, particularly concerning growing quality requests (Fold and Ponte, 2008; Ponte, 2009). In this context, individual smallholders face increased difficulties meeting the strict buyer demands in terms of quality, volume, and timely deliveries (Donovan and Poole, 2014). In this sense, cooperatives can play a central role in different domains: the promotion of farmers' coordination and collaboration, the stimulus of changes in the systems of agrarian management and the support of certifications or the development of new marketing strategies (Coq-Huelva et al., 2017) among others. In this way, cooperatives can be understood as organizations which promote the distribution of high-risk activities among farmers which have been traditionally considered risk-avoidant agents (Molla et al., 2019; Mosley and Verschoor, 2005).

In this process of collective management and individual avoidance of risks, cooperatives follow different, and sometimes partially contradictory, objectives. They have clear economic targets - as farmers' income rise - but also, strong social and even emotional aims (Battilana, 2018; Mongelli et al., 2019). Thus, the management of cooperatives has a set of specific features (Michelsen, 1994; Sayers et al., 1996). Particularly, farmers' satisfaction and commitment are essential elements in the processes of organizational development and capital accumulation of cooperatives. In this sense, they are closely related with the processes of farmers' self-selection and self-reinforcement which can have a group of local and regional spill overs (Bernard and Spielman, 2009; Chagwiza et al., 2016; Kurjańska, 2015).

Satisfaction, understood in a broader framework of worker ownership and democratic decision-making, is an especially problematic issue which depends on a broad set of factors (Homburg et al., 2006; Ingram and Simons, 2000; Rodriguez del Bosque and San Martin, 2008). Some of those factors are highly intuitive, but others have strong deliberative components (Kahneman, 2002, 2003). Generally speaking, cognition and emotions are essential elements for approaching satisfying behaviours (Oliver, 1993; Rodriguez del Bosque and San Martín, 2008). In the case of cooperatives, members' satisfaction is associated with cognitive and emotional elements derived from the existence of different kinds of social connections (Núñez-Nickel and Moyano-Fuentes, 2004).

The development of agrifood cooperatives has been one of the key policy issues globally addressed to the reduction of poverty in rural areas notably in developing countries (World Bank, 2007). Such actions have been particularly relevant in Latin America, especially in some specific value chains as coffee and cocoa (Bacon, 2005; Donovan et al., 2017; Ronchi, 2002). In this framework, Peru has historically had especially powerful policies for the development of the cooperative sector, which date back to the 1960s and 1970s (Belaunde, 1959; Brass, 2007). Moreover, cooperatives' development has been very intense in the case of the Peruvian Amazonia, because of the actions of other global agents as United Nations or USAID, being the strength of this support associated with the fight against the expansion of drug trafficking activities (Laroche et al., 2012). Further, in the past, due to the poor access and lack of infrastructure, intermediaries offer substantially lower prices to farmers than those in international markets. The co-existence of private firms and cooperatives competing for farmers' deliveries is common in the agricultural sector, especially in the coffee and cocoa crops (Wollni and Fischer, 2015). In this context, the present study is located in the Peruvian jungle, specifically in Tocache province, in the San Martin region, which has been considered Peru's 'cocaine capital' (Van Dun, 2009) being cocoa one of the strategic crops able to break the vicious cycle of farming of coca leaves (UNODC, 2015). Tocache area is featured by the existence of a strong cooperative structure that is led by the Central Cacao de Aroma Cooperative (second-degree cooperative), followed by small cooperatives and associations (first-degree cooperatives) located in diverse districts within the province. Therefore, the objective of this study is two-fold. On one hand, the factors that influence farmers' satisfaction and commitment will be determined as key elements to approach the organizational performance of cooperatives. On the other hand, the distribution of satisfaction among farmers and its relation will be analyzed with demographic and socio-economic features. The analysis of this case aims to enrich the literature on cooperative management in the current context of transformation of food value chains, insisting 
on elements related to behaviorist approaches that focus their attention on elements such as satisfaction, individual and social cognition or the management of emotions.

The remainder of this article is organized as follows: the second section outlines the literature review. The third section presents the methodology, which includes the survey data used in this research that involves socioeconomic and marketing variables among others in our analysis. The fourth section describes the results. Finally, discussion points, the main conclusions and policy recommendations derived from the main findings of this study are presented in the fourth section.

\section{Food value chains, cooperatives and its relationship with farmers' satisfaction}

In this section, two main issues will be reviewed: first, the particular features of cooperatives' organization will be explored in the broad context of the current food commodity chains. Second, cooperative members' behavior will be analyzed, considering different cognitive and emotional issues, particularly on their satisfaction and commitment towards the cooperative.

Price trends, have been increasingly affected by the agro-food value chains transformations, which have been shaped also due to the emergence of new agents (large-scale distributors) with strong bargaining power and a tendency to exert a rising pressure on the prices paid to farmers (Dolan and Humphrey, 2000; Hattersley and Dixon, 2010). In addition, agro-food value chains are increasingly fragmented (Fold and Ponte, 2008; Ponte, 2009). The growing demand for quality is generating differentiated niche segments, in which it is possible to obtain premium prices according to the fulfilment of different labels and standards: organic, PDO, integrated production, fair trade, etc. (Bacon 2005; Barham, 2003; Bowen and Mutersbaugh, 2014; Ronchi, 2002). Alternatively, the demand for quality is also transforming the non-differentiated segments of the chains because of the role of new standards and certifications (Campbell, 2005; Sonnino and Marsden, 2006). In this context of broad reorganization, the promotion of cooperatives has often been seen as a way to break out poverty traps (Hellin et al., 2009; Holloway et al., 2000; Trebbin, 2014).

Small farmers particularly in developing countries often experience poverty-related problems connecting with the organization of the systems of agrarian management, having limited resources for investing and developing competitive advances (Chagwiza et al., 2016) including limited mechanization and technological backwardness. Second, the long distance of these producers from the final markets results in poor access to final markets, leading to excessive dependence on intermediaries, generates a general deprivation of power to bargain (Bernard et al., 2008; Verhofstadt and Maertens, 2015). Additionally, due to other social reasons, farmers often behave as risk-avoiding agents (Mosley and Verschoor, 2005). Cooperatives can act as institutions that accept greater risks allowing the development of new businesses (Molla et al., 2019). Thus, by pooling their resources and jointly managing their sales, farmers could relatively be protected from the high-risk activities that need to be carried out. In this way, cooperatives can play the role of key agents in broader processes of industrial upgrading and development of quality productions (Coq-Huelva et al., 2012). However, the development of the cooperatives not always guarantees the achievement of this potential set of benefits (Barham and Chitemi, 2009; Barrett, 2008; Ruben and Fort, 2012). If cooperatives fail to achieve the expected results, they have to dissolve (Markelova et al., 2009; Poulton et al., 2010). Under this situation, what are the factors which explain cooperatives' failure or success? It is generally recognized the existence of a complex set of elements that are mostly unknown (Fischer and Qaim, 2012) or the absence of pre-defined patterns. Or said in other words: 'there has been limited discussion on the long and often turbulent process by which cooperatives develop over time and the viable options for shortcuts' (Donovan et al., 2017: 169).

It is known that in farmers' cooperatives, members play a double role as owners and suppliers. In their role as owners, the prevailing objective of farmers is maximizing the cooperative's turnover and profits. In their role as suppliers, the most critical issue for the farmers is obtaining higher prices (Núñez-Nickel and Moyano-Fuentes, 2004). Even though they are contradictory, both objectives are simultaneously searched in a different degree. In this sense, the prevalence of one or another approach and its impact on members' 
satisfaction must be understood as the result from the interplay of intricate social constructions with relevant discursive features (Lawrence et al., 1999; Montgomery et al., 2012). In this respect, keeping farmers' satisfaction among an organization is an essential issue for the generation of collective bias able to promote cooperative behaviors (Cummins and Nistico, 2002). For instance, they are particularly relevant cognitive bias in the way in which members' intangible benefits (such as formation, technical assessments, services not provided by markets, etc.) which are hard to perceive and assess because they are difficult to measure in a totally objective way (Battilana, 2018; USDA Rural Business - Cooperative Service, 1990).

Emotional issues are closely related with everyday life (Jacobsen, 2018). In the case of farmers' this daily life is associated with the effective exercise of their political rights. As cooperatives imply that farmers have ownership and rights to democratic decision-making, satisfaction is also associated with how those issues operate (Ingram and Simons, 2000; Simons and Ingram, 1997). In this sense, membership in a co-operative implies long-term activities (for instance, participation in decision-making processes) with strong emotional implications (Stürmer et al., 2005). Pro-social emotions are, in general on the bases of the development of human cooperation (Bowles and Gintis, 2003). Thus, it could be asserted that the development of cooperatives is strongly related to the management of pro-social emotions among their members (Gintis, 2004). Elements such as pride of belonging to a cooperative, trust between members in general and trust in directive boards in particular (involving empathy and admiration), the existence of effective dynamics of participation (involving shame and guilt for not fulfilling a task) and the feeling that one's contributions are considered, etc. are strongly related to pro-social emotions. Farmers' satisfaction is a behavioral concept with a wide academic genealogy (Brown, 2004; Oliver, 2014; Schwartz, 2002). Thus, the following hypothesis was formulated:

H1: The satisfaction of members of cooperatives is a complex outcome that reflects both cognitive and emotional factors.

The prevalence of these emotions in large human groups is strongly associated with elements such as commitment which has been defined by Fulton (1999: 423) as 'the preference of cooperative members to patronize a cooperative even when the cooperative's price or service is not as good as that provided by an IOF - Investors Owned Firms-'. Such definition understands farmers' commitment as a preference operating even when the objective elements which explain farmers' satisfaction (the achievement of better economic results) are not properly acting, at least in the short term. Farmers' commitment is an essential element for ensuring the prevalence of cooperatives because committed members are less likely to abandon the cooperative or to sell outside when alternative buyers as intermediaries offer, particularly in the short term, better prices or services (Cechin et al., 2013).

At the same time, commitment, as satisfaction, must also be understood as a cognitive and emotional output (Barraud-Didier et al., 2012; Cooper-Hakim and Viswesvaran, 2005; Deng et al., 2013; Homburg et al., 2006; Oliver, 1993; Rodriguez del Bosque and San Martin, 2008). From a cognitive perspective, satisfaction is the result of a favorable correspondence between the farmers' expectations and their experiences inside the cooperatives (Grashuis and Cook, 2019). Commitment is a cognitive issue because farmers must have trust on the higher economic performance of cooperatives in the medium and the long term (Tan and Lim, 2009). That is, from a cognitive perspective, commitment does not imply an irrational decision-making. Additionally, commitment is also an emotional issue because pro-social emotions are actively involved in its generation (Jussila et al., 2012). Satisfied and highly committed members are more likely to support their cooperative by participating in all cooperative activities (Dakurah et al., 2005; Grashuis and Cook, 2019). Thus, cooperatives formed by committed members or at least with a definite core of committed members will have access to more resources, particularly guaranteeing stable levels of cooperative turnover (Liang and Hendrikse, 2013). In fact, one of the major competitive advantages of cooperatives is their ability to ensure access to specific resources (Núñez-Nickel and Moyano-Fuentes, 2004). Consequently, farmers' commitment allows overcoming situations of systemic stress allowing processes of reinforcing and organizational development of cooperatives (Bernard and Spielman, 2009; Chagwiza et al., 2016). Finally, cooperatives are also normative organizations with relevant civic and even ideological issues. As a result, 
the respect of a certain sense of fairness is closely related with the general framework of satisfaction and commitment (Simons and Ingram, 1997). Cooperatives tend to produce better results when they are perceived as equitable, transparent and competent in addressing their members' specific needs (Biswas, 2015; Chen et al., 2007). That is, farmers' satisfaction and commitment are inseparable from the search of a collective sense of justice and fairness in a practical implementation of moral economies (Sayer, 2007).

There are different structural and institutional elements which explain the satisfaction and commitment dissimilarity degrees among farmers (Barham and Chitemi, 2009; Hellin et al., 2009; Narrod et al., 2009). Such heterogeneity must be a result of the presence of different farmers' profiles. Some of them are associated to demographic factors, such as age, experience as a farmer or family size (Ahmed and Mesfin, 2017; Bernard and Spielman, 2009; Ma et al., 2017). Other factors have mostly socio-economic roots, such as family income, levels of education or extension of farms (Ahmed and Mesfin, 2017; Buadi et al., 2013; Österberg and Nilsson, 2009). There are also elements related to mentality, such as the differing positions of individuals with respect to collective action (Hansen et al., 2002; Wollni and Fischer, 2015). Consequently, for the analysis of this topic, a second hypothesis was generated:

H2: There are broad differences in levels of satisfaction and commitment among cooperative members being such differences closely related with demographic and socio-economic issues.

\section{Methods and materials}

Considering our interests in analyzing the impact of the benefits that cocoa cooperatives offer to their members, the study focused on a set of cooperatives specialized in cocoa production and marketing strategies. The analysis has covered different steps. First, depth interviews have been made to authorities of ward offices of the Tocache districts; authorities from Prodatu II-DEVIDA (a project that involves alternative crop development for coca leaves) the managers presidents, and management workers of the first and second order cooperatives; and finally, cooperative members in order to approach to their everyday practices as farmers and particularly to their systems of agrarian management and cocoa sales and marketing. This qualitative phase has allowed us to approach to some of the most important cocoa institutions of Tocache Area, as cooperatives, or Prodatu II-DEVIDA.

Farmers, especially considering the history of coca cultivation in the area, are especially reluctant to talk to outsiders about issues which could have any economic implication. Thus, farmers' approach was made with the help of local officials working in cooperatives and public agencies (as Prodatu II-DEVIDA). After in-depth interviews, a structured questionnaire was administered with the support of different institutions and particularly Prodatu II-DEVIDA. Primary data were gathered between January and June 2015 in six districts in Tocache (Pólvora, Tocache, Cholón, Uchiza, Mishollo and Nuevo Progreso), where the first-order cooperatives are located. The whole area was covered to make the sample representative. Farmers were approached randomly at cocoa farms and interviewed face-to-face on the occasion of cooperative meetings or weekly cocoa deliveries.

The total population of the cooperatives in the six districts included 630 associated cocoa farmers. The sample size involved 150 associated cocoa farmers, being reached $23.8 \%$ of the total population. Questionnaire was quite long, so we considered exclusively such farmers who answered all the questions. Considering that farmers' selection has been made randomly and assuming that it can be assimilated to a simple random sample, there was a sampling error of $7 \%$ with a $95 \%$ confidence interval. Although the selection was made on a random basis, subsequent calculations have been made to ensure that a certain proportion has been maintained among the members of the co-operatives interviewed.

The study used a Likert scale questionnaire ranging from 1 (strongly agree) to 7 (strongly disagree) to measure the perceptions of internal and external factors related to the cooperative through which cocoa farmers distribute their crops. Indicator scales were developed by a wide-ranging review of the prior literature to 
provide quantitative and qualitative assessments regarding cooperative satisfaction and commitment (Bernard and Spielman, 2009; Gebremedhin et al., 2009; Wollni and Zeller, 2007). Personal (owner), household, socio-economic status, institutional and marketing variables were also included in the analysis (Table 1). A panel of experts pre-reviewed the questionnaire in order to ensure content validity, and a pilot test was conducted among several farmers and directors of cooperatives.

Data were analyzed using SPSS 22.0 (IBM, Armonk, NY, USA). We used a combination of various multivariate statistical techniques adapted to the objectives and hypotheses of our study and justified by the objectives of the analysis. First, a factor analysis (FA) with a principal component analysis (PCA) method with orthogonal varimax rotation was used for identifying and grouping the set of causes that explain farmers' satisfaction. FA is especially adapted to analyze behavioral issues. Moreover, this technique will allow differentiating the objective and subjective, cognitive and emotional elements that explain farmers' satisfaction. Thus, this technique is closely related with the main arguments exposed in the second epigraph of this article and particularly with the testing of the Hypothesis 1 . FA is statistically speaking a relatively simple and intuitive technique which allows identifying the underlying causes that explain farmers' satisfaction. In this sense, the FA is able to summarize a high percentage of the variances of the original variables, reducing the items to a few factors. In any case, FA is a technique used in this case for exploratory purposes being its coverage and validity associated with the degree to which the original variables reflect the multiplicity of dimensions that explain farmers' satisfaction.

FA has been applied in such a way as to ensure that all the initial variables are sufficiently represented. All of the 22 original variables included in factor solutions have communalities higher than 0.5 (Hair et al., 1999). The Kaiser's criterion for retaining factors with eigenvalues greater than 1 as well as the scree plot method was used in the analysis. Therefore, the four factors finally included have a significant explanatory capacity. The reliability and internal consistency of this approach was verified using Cronbach's $\alpha$ indicator with satisfactory values $(\alpha \geq 0.8)$ (Hair et al., 1999; Nunnally and Bernstain, 1994). The average variance extracted was over 0.5 for all the components, and the composite reliability in all cases was higher than 0.80. Regarding the convergent validity, each factor loading was over 0.5 (Bagozzi and Yi, 1988) (Table 2).

In a second step of the analysis, FA factors were used as input variables in a hierarchical clustering analysis (HCA). The aims of this technique were to classify farmers and to identity their different profiles with as few theoretical assumptions as possible. Thus, HCA allows analyzing farmers' heterogeneity while simultaneously identifying homogeneous groups among them. The limits of cluster analysis are related to the impossibility of a priori determining the number of groups. In our case, firstly, HCA is addressed to determine the patterns that

Table 1. Summary statistics $(\mathrm{n}=150)$.

\begin{tabular}{llllll}
\hline Variable & Description & Min. & Max. & Mean & SD $^{\mathbf{1}}$ \\
\hline Age & farmer's age (years) & 20 & 82 & 45.43 & 11.36 \\
Education & farmer's education (years) & 0 & 16 & 7.49 & 3.44 \\
Cocoaincome & percentage of cocoa income & 0.1 & 1.0 & 0.84 & 0.20 \\
Land & cocoa land (ha) & 1.0 & 14.00 & 3.04 & 1.76 \\
Organicprod & tons of organic cocoa production (tons/ha/year) & 0 & 16 & 3.16 & 2.63 \\
Conventionalprod & tons of conventional cocoa production (tons/ha/year) & 0 & 11 & 2.31 & 2.01 \\
Experience & experience in cocoa cultivation (years) & 2 & 30 & 7.82 & 4.12 \\
Cocoaprof & cocoa profit (sales/year) & 400 & 25,600 & $5,986.11$ & $2,923.62$ \\
Cocoaprice & cocoa price (sales/kg) & 7 & 9 & 7.53 & 0.50 \\
Household & number of household members & 1 & 5 & 3.41 & 1.28 \\
Coca & years of coca cultivation & 1 & 20 & 5.03 & 3.59 \\
Income & total income (sales/month) & 130 & 9,500 & $1,150.22$ & $1,028.45$ \\
\hline
\end{tabular}

${ }^{1} \mathrm{SD}=$ standard deviation. 
Table 2. Varimax rotated component matrix for principal component analysis. ${ }^{1}$

\begin{tabular}{|c|c|c|c|c|c|c|}
\hline Item & $\stackrel{\bar{E}}{\sum_{\Sigma}^{ \pm}}$ & 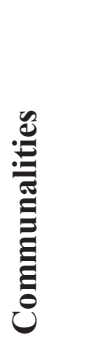 & 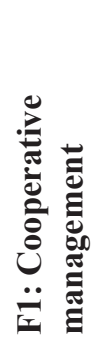 & 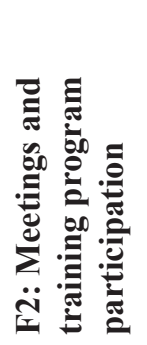 & $\begin{array}{l} \\
\\
\end{array}$ & 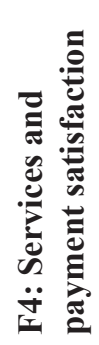 \\
\hline Cooperative provides transportation facilities & 2.41 & 0.830 & 0.85 & 0.18 & 0.22 & 0.20 \\
\hline Cooperative has standards of cocoa processing & 2.37 & 0.832 & 0.81 & 0.20 & 0.24 & 0.20 \\
\hline There is coordination of staff within the cooperative & 2.25 & 0.867 & 0.80 & 0.21 & 0.27 & 0.22 \\
\hline There is manager leadership & 2.58 & 0.741 & 0.79 & 0.12 & 0.32 & 0.15 \\
\hline Cooperative develops post-harvesting management & 2.41 & 0.785 & 0.74 & 0.32 & 0.13 & 0.09 \\
\hline Cooperative has a high management level & 2.60 & 0.757 & 0.66 & 0.27 & 0.25 & 0.23 \\
\hline $\begin{array}{l}\text { Cooperative has certifications that validate the cocoa's } \\
\text { quality }\end{array}$ & 2.11 & 0.632 & 0.61 & 0.24 & -0.06 & 0.08 \\
\hline $\begin{array}{l}\text { My interventions as a member in the general assembly } \\
\text { are considered }\end{array}$ & 2.99 & 0.775 & 0.31 & 0.79 & 0.03 & 0.16 \\
\hline Frequently I intervene in the general assembly & 2.98 & 0.818 & 0.31 & 0.74 & 0.26 & 0.23 \\
\hline $\begin{array}{l}\text { The cooperative always explains decisions that may } \\
\text { affect its members }\end{array}$ & 3.16 & 0.813 & 0.21 & 0.72 & 0.19 & 0.38 \\
\hline $\begin{array}{l}\text { I attend all meetings of the general assembly as a } \\
\text { member }\end{array}$ & 2.86 & 0.772 & 0.21 & 0.68 & 0.35 & 0.19 \\
\hline $\begin{array}{l}\text { Cooperative has competitive agricultural and } \\
\text { management training programmes }\end{array}$ & 3.07 & 0.827 & 0.26 & 0.68 & 0.30 & -0.03 \\
\hline $\begin{array}{l}\text { Cooperative provides programmes aiming to educate } \\
\text { members }\end{array}$ & 2.84 & 0.791 & 0.31 & 0.67 & 0.30 & -0.14 \\
\hline I am well informed about the results of the cooperative & 3.23 & 0.643 & 0.34 & 0.66 & 0.27 & 0.19 \\
\hline There is cooperation among cooperative members & 3.15 & 0.821 & 0.15 & 0.29 & 0.81 & 0.19 \\
\hline $\begin{array}{l}\text { There is a good management and leadership by the } \\
\text { staff of the cooperative }\end{array}$ & 3.00 & 0.765 & 0.14 & 0.27 & 0.77 & 0.09 \\
\hline Cooperative establishes good planning and objectives & 2.91 & 0.776 & 0.39 & 0.40 & 0.68 & 0.00 \\
\hline $\begin{array}{l}\text { My relation with the cooperative is a long-term } \\
\text { partnership }\end{array}$ & 2.38 & 0.733 & 0.20 & 0.36 & 0.63 & 0.38 \\
\hline I participate in the cooperative decision making & 2.87 & 0.699 & 0.26 & 0.40 & 0.62 & 0.04 \\
\hline $\begin{array}{l}\text { The services that the cooperative provides help to } \\
\text { achieve my business goals }\end{array}$ & 3.04 & 0.836 & 0.28 & 0.26 & 0.15 & 0.80 \\
\hline $\begin{array}{l}\text { I am very happy with the price paid by the cooperative } \\
\text { for the cocoa delivered }\end{array}$ & 3.15 & 0.821 & 0.38 & 0.22 & 0.16 & 0.78 \\
\hline $\begin{array}{l}\text { I feel satisfied with the price paid for the cocoa I sell to } \\
\text { the cooperative }\end{array}$ & 3.03 & 0.746 & 0.38 & 0.30 & 0.09 & 0.68 \\
\hline Cronbach's $\alpha$ & & & 0.93 & 0.90 & 0.89 & 0.82 \\
\hline Average variance extracted (AVE) & & & 0.57 & 0.50 & 0.50 & 0.57 \\
\hline Composite reliability & & & 0.90 & 0.87 & 0.83 & 0.80 \\
\hline
\end{tabular}

${ }^{1}$ Bold $=$ factor loadings. 
explain the differences between satisfied and unsatisfied farmers. Secondly, HCA is directed to analyze the demographic and socio-economic elements which are associated to different levels of farmers' satisfaction. In both cases HCA, is closely related with the testing of the Hypothesis 2 . This analysis is crucial because, on the one hand, satisfaction is a process with an individual and group component that the HCA allows us to insist on. However, it is also important because it allows us to insist on the importance in specific cases of a range of factors, which feedback each other, ultimately leading to the cooperatives' self-reinforcing processes. In HCA, the Euclidean distance method was used, as it is the most straightforward and generally accepted way of computing distances between objects in a multi-dimensional space. The centroids of those groups were used as the initial point of a Ward cluster analysis (this method uses an analysis of variance approach to evaluate the distances between clusters) in order to avoid non-classified individuals. Finally, cluster membership was assessed by calculating the total sum of squared deviations from the mean of a cluster. The criterion for fusion was that it should produce the smallest possible increase in the error sum of squares.

Finally, in the last phase of the analysis, once groups of homogeneous farmers were identified, an inquire of the main elements that explain the different levels of farmers' satisfaction was performed. To accomplish this goal, an analysis of whether there are statistically significant differences in the values of specific (demographic and socio-economic) variables between satisfied and unsatisfied farmers was done using an independent $t$-statistic test.

\section{Results}

\subsection{Perceived benefits to the cocoa cooperative members}

For the first objective, it was necessary to determine what cooperative services were perceived as important by members. As we have hypothesized (H1) following the previous literature, a mixture of cognitive and emotional factors may affect this relationship. The 22 Likert variables shown in Table 2 were considered for this analysis. The Kaiser-Meyer-Olkin statistic is 0.937, which is close to 1, and the Bartlett's measure test approximate chi-square value is 9,378.580 with 741 degrees of freedom and an associated $P$-value of 0.01 . The reduction to a four-factor solution (explaining $70.24 \%$ of the total data variance) lost less than $30 \%$ of the explanatory variance capacity of the original variables and can thus be considered very successful.

Factor 1 includes the first seven items of Table 2, which are associated with 'cooperative management'. This factor is closely associated with cognitive issues, that is, with the members' appraisal of the cooperative performance in various fields. Some of the items in this factor involve subjective elements related to the individual assessment of the managerial performance by cooperative associates (items 3, 4 and 6). However, some objective issues such as the provision of facilities for transportation, processing and post-harvesting also have a broad influence in the definition of this factor. All those elements are in line with the suggestions of the academic literature. In this sense, poor managerial decisions can negatively affect the cooperative (Amodeo, 2001). Additionally, a share in ownership and governance by members are important cooperative principles and features of human capital (Donovan and Poole, 2014). These principles are relevant to governance and to the sustainability of co-operative organizational forms (Altman, 2015).

The second factor is related to different manifestations of a more general topic that can be described as the 'Meetings and training program participation' factor (Table 2). It must be stressed that in this case satisfaction is related with participation in collective meetings and information programs. Therefore, this factor is mainly related to the assessments that farmers make about their effective feelings and behaviors related to participation. Thus, it is mostly associated with psycho-social factors related to the management of pro-social emotions. In this sense, this factor stresses that one unique feature that separates cooperatives from other business entities is their member involvement and participation in the organization's activities (Dakurah et al., 2005). In addition, in this case, participation is associated with the delivery of a specific service, a situation that can be considered to benefit members from a strictly cognitive approach. Thus, this 
factor also accounts for a certain degree of association between psycho-social and cognitive elements, even though the former elements clearly prevail.

Members can influence the cooperative at the meetings, which are a subjective assessment of their participation in the governance system (Österberg and Nilsson, 2009). The members may be more or less committed to voting for directors, transferring signals to the management, controlling the work of the board, etc. (Bhuyan, 2007). The likelihood of cooperative abandonment is higher if members perceive that their input is not valued by the management in making decisions (Bhuyan, 2007; Österberg and Nilsson, 2009). Tocache cooperatives have had directorates who were elected by a majority of the votes in their own social capitalbased structures and who were attentive to the concerns of their constituents (Melo and Hollander, 2013). Thus, the principle of equal voting rights (one member, one vote), which implies that the directors value the opinions of the small farmers, is critical, because members consider democratic control to be a fundamental aspect of cooperative participation (Österberg and Nilsson, 2009).

The third factor summarizes different elements related to 'producer-cooperative cooperation and trust'. This factor also stresses psycho-social elements mainly related to participation, commitment, trust and leadership. Social goals may include the desire to interact with other members and to develop personal and business relationships (Arcas-Lario et al., 2014; Hansen et al., 2002). These interactions and relationships are considered easier to develop in rural areas, because the social, cultural, ethnic, and economic backgrounds of the farmers are similar or homogeneous and the communities are constant (Schmidt et al., 2015). Members' perceptions of the board of directorates can be expressed in the form of their trust in the board (Grashuis and Cook, 2019; Österberg and Nilsson, 2009). Hansen et al. (2002) found that cognitive trust in the management is stronger than affective trust, and this is the case in cooperatives such as the Central Cacao de Aroma cooperative in Tocache.

The fourth factor includes items referring to 'services and payment satisfaction'. The most obvious reason farmers join co-ops is to satisfy economic goals or to improve financially (Hansen et al., 2002). The producers deliver fresh (just harvested) beans to the local collection and processing centre and receive an up-front payment for the dry weight equivalent of these beans (Laroche et al., 2012).

\subsection{Perceived benefits of cocoa cooperative members and socio-economic characteristics}

To address the testing of the Hypothesis 2, it has been analyzed how farmers' characteristics influence these four factors which have been obtained in the previous section classifying the overall population into groups. The agglomeration schedule was checked. This provides a solution for every possible number of clusters. Table 3 shows the agglomeration coefficients. The final column, titled 'change', enables us to determine the optimum number of clusters, which in this case was two, as more clustering added little to the coefficient for distinguishing between cases.

Additionally, the dendrogram (Figure 1) confirms that there are two clear groups (highly satisfied and less satisfied cooperative members).

The respective sizes and scores of the segmentation variables are reported in Table 4 according to the four factors obtained from the FA-PCA procedure. Therefore, the main variation profile is given by the differences

Table 3. Agglomeration schedule.

\begin{tabular}{llll}
\hline No. of clusters & Agglomeration last step & Coefficient this step & Change \\
\hline 2 & $1,157.468$ & 663.151 & 494.317 \\
3 & 663.151 & 477.875 & 185.276 \\
4 & 477.875 & 372.192 & 105.683 \\
\hline
\end{tabular}




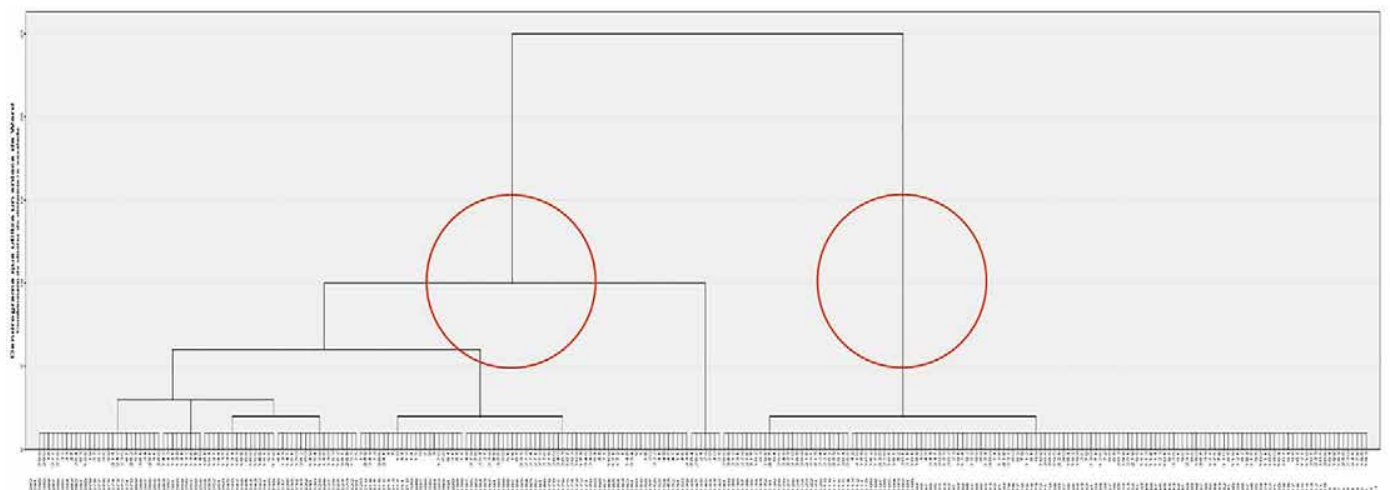

Figure 1. Dendrogram.

in the values of the factors. Some authors have concluded that it is necessary to understand the socioeconomic characteristics of producers to make judgements about the effects of different policies on economic wellbeing (Glewwe, 1991). It is important to have knowledge of each farmer, the household, the land, and the crops, among other characteristics (Melo and Hollander, 2013). Thus, the differences in socio-demographic characteristics of the farmers were analyzed in relation to the clusters to which they belong. Table 4 presents the profile of cocoa farmer segments according to the following: (1) dimensions of intrinsic and extrinsic perceptions of the cooperative; and (2) the socio-economic characteristics of the segments determined by an independent $t$-test, which provides evidence that each cluster is distinctive.

Segment 1 (51.4\% of the sample) can be typified as 'highly satisfied' cooperative members. This segment's general evaluation is positive regarding the intrinsic and extrinsic underlying opinions of the cooperative they use as a marketing channel to distribute their product. The second segment ( $48.6 \%$ of the sample) can be profiled as 'less satisfied' members who acknowledge they gave a significantly lower evaluation $(P<0.01)$ for all four factors compared to their counterparts.

Less satisfied cocoa farmers feel less pleased with the services, relationship, and general qualities (services and payment) of the cooperative they belong to. That is, the main elements which explain lower levels of satisfaction are mostly cognitive and particularly related with a lack of information, the board's insufficient skills, and the relatively high costs of selling to the cooperative, as Donovan and Poole (2014) suggests. Such climate of discontent with directive boards among some members, if not solved, can have relevant emotional effects particularly on trust between members and managers.

Regarding the demographic variables, the analyzed outcomes show that highly satisfied farmers are older than their counterparts $(P \leq 0.10)$. This confirms the conclusions of previous studies in which the age of the household head has significant relationship with cooperative membership (Ahmed and Mesfin, 2017; Bernard and Spielman, 2009; Ma et al, 2017). Education (in number of years) and farm size (in hectares) have also been cited as socio-economic characteristics that distinguish satisfied and non-satisfied members (Bernard and Spielman, 2009; Ma et al., 2017; Sturm and Smith, 1993). However, in this case, highly satisfied farmers were found to be less educated than their counterparts $(P \leq 0.10)$. This can be explained by demographic factors, being highly educated farmers often younger. Also, they are more exigent with cooperatives' activities. It can be also observed that educational levels are negatively correlated with the previous farming of coca leaves. Thus, previous coca farmers are more satisfied with cooperatives' operation probably because they are less risk-avoiding, more involved in the attainment of higher prices and more dependent of the agrarian extension activities of cooperatives for improving their systems of agrarian management.

To be a member of a cooperative, earlier studies indicated that farmers' assets also mattered, for instance, the size of the owned land (Ahmed and Mesfin, 2017). Peru is endowed with a favorable land-labor ratio 
Table 4. Profile of cocoa farmer segments $(n=150)$ regarding intrinsic and extrinsic perceptions of the cooperative and socio-economic characteristics.

\begin{tabular}{|c|c|c|c|c|}
\hline Variables & $\begin{array}{l}\text { Highly } \\
\text { satisfied } \\
\text { members }\end{array}$ & $\begin{array}{l}\text { Less } \\
\text { satisfied } \\
\text { members }\end{array}$ & $\mathbf{T}$ & $\begin{array}{l}\text { Signifi- } \\
\text { cance }\end{array}$ \\
\hline
\end{tabular}

\begin{tabular}{|c|c|c|c|c|}
\hline \multicolumn{5}{|l|}{ Factors } \\
\hline Cooperative management satisfaction ${ }^{1}$ & 1.8 & 2.82 & 11.55 & $* * *$ \\
\hline Cooperative provides transportation facilities & 1.89 & 2.89 & 6.789 & $* * *$ \\
\hline Cooperative has standards of cocoa processing & 1.55 & 2.64 & 9.383 & $* * *$ \\
\hline There is coordination of staff within the cooperative & 1.75 & 2.83 & 9.882 & $* * *$ \\
\hline There is manager leadership & 1.84 & 2.99 & 9.459 & $* * *$ \\
\hline Cooperative develops post-harvesting management & 1.9 & 2.96 & 8.312 & $* * *$ \\
\hline Cooperative has a high management level & 2.04 & 3.03 & 8.63 & $* * *$ \\
\hline Cooperative has certifications that validate the cocoa's quality & 1.84 & 2.55 & 5.359 & $* * *$ \\
\hline Meetings and training program participation ${ }^{1}$ & 2.2 & 3.46 & 14.81 & $* * *$ \\
\hline My interventions as a member in the general assembly are considered & 2.16 & 3.58 & 11.308 & $* * *$ \\
\hline Frequently I intervene in the general assembly & 2.26 & 3.51 & 10.483 & $* * *$ \\
\hline The cooperative always explains decisions that may affect its members & 2.08 & 3.51 & 13.813 & $* * *$ \\
\hline I attend all meetings of the general assembly as a member & 2.04 & 3.18 & 9.068 & $* * *$ \\
\hline Cooperative has competitive agricultural and management training programmes & 2.49 & 3.38 & 5.776 & $* * *$ \\
\hline Cooperative provides programmes aiming to educate members & 2.36 & 3.49 & 7.957 & $* * *$ \\
\hline I am well informed about the results of the cooperative & 2.16 & 3.51 & 10.902 & $* * *$ \\
\hline Producer-cooperative cooperation and trust ${ }^{1,2}$ & 1.96 & 3.35 & 15.41 & $* * *$ \\
\hline There is cooperation among cooperative members & 2.23 & 3.72 & 12.586 & $* * *$ \\
\hline There is a good management and leadership by the staff of the cooperative & 2.01 & 3.41 & 11.408 & $* * *$ \\
\hline Cooperative establishes good planning and objectives & 1.96 & 3.26 & 9.915 & $* * *$ \\
\hline My relation with the cooperative is a long-term partnership & 1.67 & 3.26 & 12.777 & $* * *$ \\
\hline I participate the cooperative decision making & 1.96 & 3.13 & 10.88 & $* * *$ \\
\hline Services and payment satisfaction ${ }^{1}$ & 2.05 & 3.55 & 17.5 & $* * *$ \\
\hline The services that the cooperative provides help to achieve my business goals & 2.14 & 3.55 & 14.634 & $* * *$ \\
\hline I am very happy with the price paid by the cooperative for the cocoa delivered & 1.82 & 3.77 & 19.315 & $* * *$ \\
\hline I feel satisfied with the price paid for the cocoa I sell to the cooperative & 2.22 & 3.34 & 8.524 & $* * *$ \\
\hline \multicolumn{5}{|l|}{ Socio-economic characteristics } \\
\hline Age & 46.58 & 44.22 & -1.77 & * \\
\hline Education $^{2}$ & 7.16 & 7.83 & 1.64 & $*$ \\
\hline Cocoaincome & 0.87 & 0.82 & -1.82 & $*$ \\
\hline Land $^{2}$ & 3.35 & 2.76 & -2.84 & $* * *$ \\
\hline Organicprod $^{2}$ & 3.47 & 2.69 & -1.88 & $*$ \\
\hline Conventionalprod & 2.16 & 2.44 & 0.92 & NS \\
\hline Experience $^{2}$ & 7.9 & 7.78 & -2.49 & NS \\
\hline Cocoaprof & $4,228.7$ & $4,381.69$ & 0.43 & NS \\
\hline Cocoaprice & 7.5 & 7.56 & 0.895 & NS \\
\hline Household $^{2}$ & 3.21 & 3.61 & 2.72 & $* * *$ \\
\hline Coca & 5.53 & 4.57 & -1.81 & $*$ \\
\hline Income $^{3}$ & $1,141.65$ & $1,169.68$ & -1.82 & * \\
\hline
\end{tabular}

${ }^{1}$ Likert scale: from 1 (strongly agree) to 7 (strongly disagree); $* * * P \leq 0.01 ; * P \leq 0.10$; NS = non-significant.

${ }^{2}$ Assumption of homogeneity of variance was violated.

${ }^{3}$ Approximate exchange rate Peruvian Sol to US\$ rate for the study: 2.835 (Central Reserve Bank of Peru 2015). 
(Higuchi et al., 2010). Cocoa land represents a form of internal capital accumulation, and highly satisfied members have more cocoa land compared to their counterparts $(P \leq 0.01)$. These highly satisfied cocoa farmers depend mostly on income from the cocoa crop, compared to traditional staples, such as bananas, cassava, coffee, palm, maize or rice. Cooperatives can increase the income of members through their bargaining power, which increases the income for the product produced. Welfare can certainly be measured from this income (Ahmed and Mesfin, 2017). A study by Gargallo Castel and Freundlich (2010) stated that related factors including satisfaction and other variables like income influence the degree of satisfaction of a person and his economic performance. Nonetheless, in this study, highly satisfied farmers receive a lower total income compared to the less satisfied farmers $(P \leq 0.10)$. Highly satisfied farmers also produce more organic cocoa than the less satisfied ones $(P \leq 0.10)$.

Previous studies determined that family size (household size) is another variable that positively affects the membership decision (Ahmed and Mesfin, 2017; Bernard and Spielman, 2009; Ma et al., 2017). In this study, however, the outcomes showed that less satisfied members have more family members than highly satisfied ones $(P \leq 0.01)$, and this fact may impact the general income required in order to sustain the family, as reported in the previous paragraph.

\section{Discussion and conclusions}

As result of the study, the hypotheses described in the second section were tested. First, the factor analysis shows that farmers' satisfaction depends on a wide range of both cognitive and emotional factors (H1), confirming the suggestions of a large portion of the academic literature on this topic (Homburg et al, 2006; Rodriguez del Bosque and San Martin, 2008). In fact, in factors 1 ('cooperative management') and 4 ('services and payment satisfaction'), the cognitive element prevails. In contrast, in factors 2 ('Meetings and training program participation') and 3 ('producer-cooperative cooperation and trust'), psycho-social elements with a strong emotional component predominate. Therefore, in the case of the Tocache cocoa cooperatives, satisfaction does not only depend on the results obtained or the services offered, but it is also a 'felt' reality with strong emotional implications (Stürmer et al., 2005). These elements are especially important in the context of Tocache, which has based its overall economy from the late 1970s to the beginning of this century on the cultivation of coca leaves for international drug trafficking. This cultivation was associated with important economic benefits but also with high levels of violence and social disintegration (Montero, 1995). In these circumstances, the reconstruction of the local society in a post-narco context after a long history of violence and drug trade is associated with the restoration of a social cohesion in which the values of commitment, trust and participation are particularly well suited. Therefore, the development of cocoa cooperatives can be considered as a successful story in the management of previously damaged pro-social emotions (Gintis, 2004).

The strong associations between satisfaction and commitment mean that there is currently a virtuous circle that favors the development of Tocache's cocoa cooperatives through processes of farmers' self-selection and self-reinforcement (Bernard and Spielman, 2009; Chagwiza et al., 2016; Kurjańska, 2015). In fact, poor satisfaction among farmers is basically explained by cognitive elements related with disagreement related to the performance of directive boards. Considering the specificities of cooperatives, it is not only necessary to implement a communication policy with clients, customers and suppliers, but also with cooperatives' members. To preserve the positive levels of feedback that currently exist, it may be helpful to managers and board members of the Central Cacao de Aroma cooperative, to develop a communication policy as an important tool for enhancing farmers' commitment (for instance with members who are currently absent).

Nonetheless, such communication policy is related with changes in the managerial procedures and the organizational structures. Thus, listening to member responses at meetings or assemblies will help cooperatives monitor member satisfaction levels related to cooperative-provided services and prices, reinforcing the effective operation of democratic procedures of decision-making (Ingram and Simons, 2000; Simons and Ingram, 1997). This monitoring will improve the cooperative system by meeting the external market 
requirements for the quantity and quality of cocoa and fostering trust and loyalty among the members. To meet this goal, the boards can establish informational systems such as a monthly bulletin, a blackboard in the local headquarters of the cooperative and updated social networks so that members come to understand that the boards' decisions are in line with the members' best interests.

Regarding psycho-social factors, specifically in the case of factor 2, it should be noted that commitment and participation are linked to the provision of formation services. In other words, subjective (participation) and objective (formation) elements are associated because both have relevant discursive features (Lawrence et al., 1999; Montgomery et al., 2012). However, beyond the transmission of knowledge, formation is understood as an opportunity for meeting and sharing. In addition, the way in which formation is often conducted allows farmers to share many of their experiences, particularly in the case of agricultural management. Considering the sensibility of farmers towards formation, communication policy of the cooperatives might insist on all the issues related with formative activities and their impacts. In this sense, more periodic meetings at the cooperatives and even directly at the farms could be established for promoting the generation of knowledge and the reinforcement of loyalty. The importance of psycho-social factors is not in conflict with the finalist and partially utilitarian character of the Tocache cocoa cooperatives. For this reason, factor 1, 'cooperative management', is connected to the way of confronting the challenges faced by the cooperatives related to post-harvest treatments, transport, certification and internal management. This means an implicit recognition by farmers of the role of cooperatives in obtaining cocoa of a quality able to be sold in international markets at substantially higher prices.

Finally, the performed cluster analysis shows that there is a wide heterogeneity in the degree of satisfaction of farmers, as the academic literature also suggests (Hellin et al., 2009; Narrod et al., 2009). This would confirm H2: there is heterogeneity in levels of satisfaction and commitment among cooperative members associated with demographic factors. The main elements that explain farmers' satisfaction are age, the extent of the farm and the previous condition of producer of coca leaves. The older the farmer is and the larger the household is, the greater the family needs regarding the income from agriculture. Additionaly, the more professional the cooperative management are viewed and the higher the services provided by the cooperative are valued by these farmers. However, education has a negative relation with farmers' satisfaction: the higher education the members have, the lesser satisfied they are with the cooperative.

The outcomes of this study will help to form recommendations for academics and practitioners in order to improve the performance of farmers' cooperatives. These recommendations should focus on the following elements. First, we have stated the centrality of member satisfaction in cooperative performance, stressing the high number of factors that are involved in member satisfaction and emphasizing the relevance of cognitive issues and particularly social processes related to the management of pro-social emotions. Second, this study identifies some independent socio-economic and demographic features that are related to farmers' satisfaction. Cooperative managers must consider these elements when managing cooperatives and seeking commitment from their members in order to have an inclusive membership, taking into account the farmers' participatory decision-making that would finally impact on a better economic performance for the cooperative and the members. With regard to researchers, new evidence has been provided regarding the satisfaction of cooperative members and the factors that affect them in the context of a developing country.

It is necessary to mention that certain limitations were encountered in this research. Restricting the study to a very specific region had some advantages, as it made it possible to isolate the phenomena of interest for a close examination. Nonetheless, this study is subject to constraints inherent to this type of research. Even though the results found in this study could be applicable to similar contexts, the most important limitation is the fact that the study focuses on members of cooperatives in a discrete geographical area that is Tocache. Therefore, it would be interesting to analyze cooperatives in other geographical areas, expanding the scope of this particular study. Methodologically speaking, as the factor analysis was exploratory, further empirical support for the model is needed. Ideally, future research could use the attributes and factors presented here to conduct a confirmatory test of the model. Researchers and managers of farmer cooperatives are encouraged 
to use the scales developed here to study the level of cocoa farmer satisfaction with their cooperative while accounting for their socio-economic characteristics in order to understand, in depth, the psychological and social sides of the economic factors at play.

\section{Acknowledgements}

Our gratitude goes out to the annual internal grant 2016 promoted by the vice-presidency for research at Universidad del Pacífico (Lima, Perú), and also to Edinov Anchahua, director of the Prodatu II-DEVIDA project for his support on the survey application.

\section{References}

Ahmed, M.H. and H.M. Mesfin. 2017. The impact of agricultural cooperatives membership on the wellbeing of smallholder farmers: empirical evidence from eastern Ethiopia. Agricultural and Food Economics 5: 6.

Altman, M. 2015. Cooperative organizations as an engine of equitable rural economic development. Journal of Co-operative Organization and Management 3: 14-23.

Amodeo, N.B.P. 2001. Be more cooperative to become more competitive. Journal of Rural Cooperation 29(2): 115-124.

Arcas-Lario, N., J.F. Martín-Ugedo and A. Mínguez-Vera. 2014. Farmers' satisfaction with fresh fruit and vegetable marketing Spanish cooperatives: an explanation from Agency Theory. International Food and Agribusiness Management Review 17(1): 127-146.

Bacon, C. 2005. Confronting the coffee crisis: can fair trade, organic, and specialty coffees reduce smallscale farmer vulnerability in northern Nicaragua? World Development 33(3): 497-511.

Bagozzi, R.P. and Y. Yi. 1988. On the evaluation of structural equation models. Journal of the Academy of Marketing Science 16(1): 74-94.

Barham, E. 2003. Translating terroir: the global challenge of French AOC labeling. Journal of Rural Studies 19(1): 127-138.

Barham, J. and C. Chitemi. 2009. Collective action initiative to improve marketing performance: lessons from farmer groups in Tanzania. Food Policy 34: 53-59.

Barraud-Didier, V., M.C. Henninger and A. El Akremi. 2012. The relationship between members' trust and participation in governance of cooperatives: the role of organizational commitment. International Food and Agribusiness Management Review 15(1): 1-24.

Barrett, C.B. 2008. Smallholder market participation: concepts and evidence from eastern and southern Africa. Food Policy 33: 299-317.

Battilana, J. 2018. Cracking the organizational challenge of pursuing joint social and financial goals: social enterprise as a laboratory to understand hybrid organizing.M@n@gement 21(4):1278-1305.

Belaunde, F. 1959. La conquista del Perú por los peruanos. Ediciones Tawantinsuyu, Lima, Peru.

Bernard, T. and D.J. Spielman. 2009. Reaching the rural poor through rural producer organizations? A study of agricultural marketing cooperatives in Ethiopia. Food Policy 34(1): 60-69.

Bernard, T., A.S. Taffesse and E. Gabre-Madhin. 2008. Impact of cooperatives on smallholders' commercialization behavior; evidence from Ethiopia. Agricultural Economics 39: 147-161.

Bhuyan, S. 2007. The 'people' factor in cooperatives: an analysis of members' attitudes and behavior. Canadian Journal of Agricultural Economics 55(3): 275-298.

Biswas, S.N. 2015. Organizational behaviour research in rural producers' cooperatives: a neglected domain. International Journal of Rural Management 11(1): 40-59.

Bowen, S. and T. Mutersbaugh. 2014. Local or localized? Exploring the contributions of Franco-Mediterranean agrifood theory to alternative food research. Agriculture and Human Values 31: 201-213.

Bowles, S. and H. Gintis. 2003. Origins of human cooperation, genetic and cultural evolution of cooperation. In: P. Hammerstein (ed.) Genetic and cultural evolution of cooperation. MIT Press, Cambridge, MA, USA, pp. 429-443. 
Brass, T. 2007. How agrarian cooperatives fail: lessons from 1970s Peru. The Journal of Peasant Studies 34(2): 240-287.

Brown, R. 2004. Consideration of the origin of Herbert Simon's theory of 'satisficing' (1933-1947). Management Decision 42(10): 1240-1256.

Buadi, D.K., K.A. Anaman and J.A. Kwarteng. 2013. Farmers' perceptions of the quality of extension services provided by non-governmental organisations in two municipalities in the Central Region of Ghana. Agricultural Systems 120: 20-26.

Campbell, H. 2005. The rise and rise of EurepGAP: the European (re) invention of colonial food relations? International Journal of Sociology of Agriculture and Food 13(2): 1-19.

Cechin, A., J. Bijman, S. Pascucci and O. Omta. 2013. Decomposing the member relationship in agricultural cooperatives: implications for commitment. Agribusiness 29(1): 39-61.

Chagwiza, C., R. Muradian and R. Ruben. 2016. Cooperative membership and dairy performance among smallholders in Ethiopia. Food Policy 59: 165-173.

Chen, M., R. Jhavala, R. Kanbur and C. Richards. 2007. Membership-based organizations of the poor: concepts, experience and policy. In: M. Chen, R. Jhabvala, R. Kanbur and C. Richards (eds.) Membershipbased organizations of the poor. Routledge, London, UK, pp. 3-31.

Cooper-Hakim, A. and C. Viswesvaran. 2005. The construct of work commitment: testing an integrative framework. Psychological Bulletin 131(2): 241-259.

Coq-Huelva, D., J. Sanz-Cañada and F. Sánchez-Escobar. 2017. Values, conventions, innovation and sociopolitical struggles in a local food system: conflict between organic and conventional farmers in Sierra de Segura. Journal of Rural Studies 55: 112.

Coq-Huelva, D., M.D. García-Brenes and A. Sabuco-i-Cantó. 2012. Commodity chains, quality conventions and the transformation of agro-ecosystems: olive groves and olive oil production in two Andalusian case studies. European Urban and Regional Studies 19(1): 77-91.

Cummins, R.A. and H. Nistico. 2002. Maintaining life satisfaction: the role of positive cognitive bias. Journal of Happiness Studies 3(1): 37-69.

Dakurah, H.A., E.W. Goddard and N. Osuteye. 2005. Attitudes towards and satisfaction with cooperatives in Alberta: a survey analysis. In: American Agricultural Economics Association Annual Meeting. July 24-27, 2005. Providence, RI, USA.

Deng, W.J., M.L. Yeh and M.L. Sung. 2013. A customer satisfaction index model for international tourist hotels: integrating consumption emotions into the American Customer Satisfaction Index. International Journal of Hospitality Management 35: 133-140.

Dolan, C. and J. Humphrey. 2000. Governance and trade in fresh vegetables: the impact of UK supermarkets on the African horticulture industry. Journal of Development Studies 37(2): 147-176.

Donovan, J. and N. Poole. 2014. Changing asset endowments and smallholder participation in higher value markets: evidence from certified coffee producers in Nicaragua. Food Policy 44: 1-13.

Donovan, J., T. Blare and N. Poole. 2017. Stuck in a rut: emerging cocoa cooperatives in Peru and the factors that influence their performance. International Journal of Agricultural Sustainability 15(2): 169-184.

Fischer, E. and M. Qaim. 2012. Linking smallholders to markets: determinants and impacts of farmer collective action in Kenya. World Development 40(6): 1255-1268.

Fold, N. and S. Ponte. 2008. Are (market) stimulants injurious to quality? Liberalization, quality changes, and the reputation of African coffee and cocoa exports. In: N. Fold and M.N. Larsen (eds.) Globalization and restructuring of African commodity flows. Nordiska Afrikainstitutet, Uppsala, Sweden, pp. 129-155.

Fulton, M. 1999. Cooperatives and member commitment. The Finnish Journal of Business Economics 4: 418-437.

Gargallo Castel, A. and F. Freundlich. 2010. Percepciones de los socios y no socios cooperativistas sobre la satisfacción laboral. Revista de Estudios Cooperativos 103: 33-58.

Gebremedhin, B., M. Jaleta and D. Hoekstra. 2009. Smallholders, institutional services, and commercial transformation in Ethiopia. Agricultural Economics 40: 577-586.

Gintis, H. 2004. The genetic side of gene-culture coevolution: internalization of norms and prosocial emotions. Journal of Economic Behavior \& Organization 53: 57-67. 
Glewwe, P. 1991. Investigating the determinants of household welfare in Côte d'Ivoire. Journal of Development Economics 35(2): 307-337.

Grashuis, J. and M.L. Cook. 2019. A structural equation model of cooperative member satisfaction and long-term commitment. International Food and Agribusiness Management Review 22(2): 247-263.

Hair, J.F., R.E. Anderson, R.L. Tatham and W.C. Black. 1999. Análisis multivariante. Prentice Hall, Madrid, Spain.

Hansen, M.H., J.L. Morrow Jr. and J.C. Batista. 2002. The impact of trust on cooperative membership retention, performance, and satisfaction: an exploratory study. International Food and Agribusiness Management Review 5: 41-59.

Hattersley, L. and J. Dixon. 2010. Supermarkets, food systems and public health: facing the challenges. In: G. Lawrence, K. Lyons and T. Wallington (eds.) Food security, nutrition and sustainability. Earthscan, London, UK, pp. 188-203.

Hellin, J., M. Lundy and M. Meijer. 2009. Farmer organization, collective action and market access in MesoAmerica. Food Policy 34: 16-22.

Higuchi, A., M. Moritaka and S. Fukuda. 2010. An analysis of the Peruvian jungle cocoa farmers: acopagro cooperative vs intermediaries - a case of study. Agris on-line Papers in Economics and Informatics 2(4): 3-10.

Holloway, G., C. Nicholson, C. Delgado, S. Staal and S. Ehui. 2000. Agroindustrialization through institutional innovation transaction costs, cooperatives and milk-market development in the east-African highlands. Agricultural Economics 23: 279-288.

Homburg, C., N. Koschate and W.D. Hoyer, 2006. The role of cognition and affect in the formation of customer satisfaction: a dynamic perspective. Journal of Marketing 70(3): 21-31.

Ingram, P. and T. Simons. 2000. State formation, ideological competition, and the ecology of Israeli workers' cooperatives, 1920-1992. Administrative Science Quarterly 45(1): 25-53.

Jacobsen, M.H. (ed.) 2018. Emotions, everyday life and sociology. Routledge, London, UK.

Jussila, I., N. Byrne and H. Tuominen. 2012. Affective commitment in co-operative organizations: what makes members want to stay? International Business Research 5(10): 1.

Kahneman, D. 2002. Maps of bounded rationality: a perspective on intuitive judgment and choice. Nobel Prize Lecture 8: 351-401.

Kahneman, D. 2003. A perspective on judgment and choice: mapping bounded rationality. American Psychologist 58(9): 697.

Kurjańska, M. 2015. A cooperative Peru: is centralisation of cooperatives better for local development? Development in Practice 25(3): 306-320.

Laroche, K., R. Jiménez and V. Nelson. 2012. Assessing the impact of Fairtrade for Peruvian coca farmers. Natural Resources institute, University of Greenwich. Available at: https://tinyurl.com/qssew77

Lawrence, T.B., N. Phillips and C. Hardy. 1999. Watching whale watching: exploring the discursive foundations of collaborative relationships. The Journal of Applied Behavioral Science 35(4): 479-502.

Liang, Q. and G. Hendrikse. 2013. Core and common members in the genesis of farmer cooperatives in China. Managerial and Decision Economics 34(3-5): 244-257.

Ma, W., A. Abdulai and R. Goetz. 2017. Agricultural cooperatives and investment in organic soil amendments and chemical fertilizer in China. American Journal of Agricultural Economics 100(2): 502-520.

Markelova, H., R. Meinzen-Dick, J. Hellin and S. Dohrn. 2009. Collective action for smallholder market access. Food Policy 34: 1-7.

Melo, C.J. and G.M. Hollander. 2013. Unsustainable development: alternative food networks and the Ecuadorian Federation of Cocoa Producers, 1995-2010. Journal of Rural Studies 32: 251-263.

Michelsen, J. 1994. The rationales of cooperative organizations. Annals of Public and Cooperative Economics 65(1): 13-34.

Molla, A., J. Beuving and R. Ruben. 2019. Risk aversion, cooperative membership, and path dependences of smallholder farmers in Ethiopia. Review of Development Economics 24(1): 167-187.

Mongelli, L., F. Rullani, T. Ramus and T. Rimac. 2019. The bright side of hybridity: exploring how social enterprises manage and leverage their hybrid nature. Journal of Business Ethics 159: 301-305. https:// doi.org/10.1007/s10551-018-4050-8 
Montero, J.L. 1995. La economía cocalera en el Perú: implicancias sobre las migraciones y el medio ambiente. Apuntes: Revista de Ciencias Sociales 36: 103-119.

Montgomery, A.W., P.A. Dacin and M.T. Dacin. 2012. Collective social entrepreneurship: collaboratively shaping social good. Journal of Business Ethics 111(3): 375-388.

Mosley, P. and A. Verschoor. 2005. Risk attitudes and the 'vicious circle of poverty'. The European Journal of Development Research 17(1): 59-88.

Narrod, C., D. Roy, J. Okello, B. Avendaño, K. Rich and A. Thorat. 2009. Public-private partnerships and collective action in high value fruit and vegetable supply chains. Food Policy 34(1): 8-15.

Nunnally, J.C. and I.H. Bernstein. 1994. Psychometric theory. McGraw-Hill, New York, NY, USA.

Núñez-Nickel, M. and J. Moyano-Fuentes. 2004. Ownership structure of cooperatives as an environmental buffer. Journal of Management Studies 41(7): 1131-1152.

Oliver, R.L. 1993. Cognitive, affective, and attribute bases of the satisfaction response. Journal of Consumer Research 20(3): 418-430.

Oliver, R.L. 2014. Satisfaction: a behavioral perspective on the consumer. Routledge, London, UK.

Österberg, P. and J. Nilsson. 2009. Members' perception of their participation in the governance of cooperatives: the key to trust and commitment in agricultural cooperatives. Agribusiness 25(2): 181-197.

Ponte, S. 2009. Governing through quality: conventions and supply relations in the value chain for South African wine. Sociologia Ruralis 49(3): 236-257.

Poulton, C., A. Dorward and J. Kydd. 2010. The future of small farms: new directions for services, institutions, and intermediation. World Development 38(10): 1413-1428.

Rodriguez del Bosque, I. and H. San Martín. 2008. Tourist satisfaction a cognitive-affective model. Annals of Tourism Research 35(2): 551-573.

Ronchi, L. 2002. The impact of fair trade on producers and their organizations: a case study with coocafé in Costa Rica. Working Paper No. 11. Policy Research Unit, University of Sussex, Sussex, UK.

Ruben, R. and R. Fort. 2012. The impact of fair trade certification for coffee farmers in Peru. World Development 40(3): 570-582.

Sayer, A. 2007. Moral economy as a critic. New Political Economy 12(2): 261-270.

Sayers, D.M., R.L. Kilmer and A.M. Flambert. 1996. Satisfaction evaluation of milk handlers by southern US dairy farmers. Journal of Agricultural and Applied Economics 28: 313-321.

Schmidt, S., W. Magigi and B. Godfrey. 2015. The organization of urban agriculture: farmer associations and urbanization in Tanzania. Cities 42: 153-159.

Schwartz, H. 2002. Herbert Simon and behavioral economics. The Journal of Socio-Economics 31(3): 181-189.

Simons, T. and P. Ingram. 1997. Organization and ideology: kibbutzim and hired labor, 1951-1965. Administrative Science Quarterly 42(4): 784-813.

Sonnino, R. and T. Marsden. 2006. Beyond the divide: rethinking relationships between alternative and conventional networks in Europe. Journal of Economic Geography 6(2): 181-199.

Sturm, L.S. and F.J. Smith. 1993. Bolivian farmers and alternative crops: some insights into innovation adoption. Journal of Rural Studies 9(2): 141-151.

Stürmer, S., M. Snyder and A.M. Omoto. 2005. Prosocial emotions and helping: the moderating role of group membership. Journal of Personality and Social Psychology 88(3): 532.

Tan, H.H. and A.K. Lim. 2009. Trust in coworkers and trust in organizations. The Journal of Psychology 143(1): 45-66.

Trebbin, A., 2014. Linking small farmers to modern retail through producer organizations - experiences with producer companies in India. Food Policy 45: 35-44.

United Nations Office on Drugs and Crime (UNODC). 2015. Peru-informe monitoreo de cultivos de coca 2014. UNODC, Vienna, Austria. Available at: https://www.unodc.org/documents/crop-monitoring/ Peru/Peru_Informe_monitoreo_coca_2014_web.pdf

United States Department of Agriculture Rural Business - Cooperative Service. 1990. Farmer cooperative in the United States. Available at: https://www.rd.usda.gov/files/cir1sec3.pdf

Van Dun, M.E.H. 2009. Cocaleros: violence, drugs and social mobilization in the post-conflict Upper Huallaga Valley, Peru. Rozenberg Publishers, Amsterdam, the Netherlands. 
Verhofstadt, E. and M. Maertens. 2015. Can agricultural cooperatives reduce poverty? The heterogeneous impact of cooperative membership on farmers' welfare in Rwanda. Applied Economic Perspectives and Policy 37: 86-106.

Wollni, M. and E. Fischer. 2015. Member deliveries in collective marketing relationships: evidence from coffee cooperatives in Costa Rica. European Review of Agricultural Economics 42(2): 287-314.

Wollni, M. and M. Zeller. 2007. Do farmers benefit from participating in specialty markets and cooperatives? The case of coffee marketing in Costa Rica. Agricultural Economics 37(2-3): 243-248.

World Bank. 2007. World development report 2008. The World Bank, Washington, DC, USA. 